\title{
The Impact of Equity Information as An Important Factor in Assessing Business Performance
}

\author{
Katarína Tasáryová * and Renáta Pakšiová * \\ Department of Accounting and Auditing, University of Economics in Bratislava, 85235 Bratislava, Slovakia \\ * Correspondence: katarina.tasaryova@euba.sk (K.T.); renata.paksiova@euba.sk (R.P.)
}

check for updates

Citation: Tasáryová, K.; Pakšiová, R. The Impact of Equity Information as An Important Factor in Assessing Business Performance. Information 2021, 12, 85. https://doi.org/ $10.3390 /$ info12020085

Academic Editors: Antonin Pavlicek and Petr Doucek

Received: 31 January 2021

Accepted: 16 February 2021

Published: 18 February 2021

Publisher's Note: MDPI stays neutral with regard to jurisdictional claims in published maps and institutional affiliations.

Copyright: (c) 2021 by the authors. Licensee MDPI, Basel, Switzerland. This article is an open access article distributed under the terms and conditions of the Creative Commons Attribution (CC BY) license (https:/ / creativecommons.org/licenses/by/ $4.0 /)$.

\begin{abstract}
Assessing the business performance is an important aspect of almost all economic decisions at the microeconomic and macroeconomic level, in the short and long term. Information about the partners' relationship to the business, their interest in the evaluation of investments can be explained by various indicators. It is relevant to understand the dependencies of the business performance and the amount of equity, while negative equity can be considered as critical information of existence. The purpose of quantitative research is to identify the relationship between reported negative equity and the business performance in Slovakia on an exhaustive sample of financial data of businesses with negative equity in the period 2014-2018. The business performance with negative equity is assessed through the Altman Z-score and the IN05 index, by classifying businesses into bankruptcy, prosperity and gray zones. Pearson's correlation analysis between negative equity and Altman Zscore performance confirms the strong direct relationship between negative equity and the bankruptcy zone, the weaker indirect relationship between negative equity and the gray zone, and almost no dependence of negative equity and prosperity zone. In the case of the IN05 index, a low correlation was found between negative equity and all three zones. Although businesses with negative equity are in a bankruptcy zone, they do not have to close automatically, but they have to improve resource management, in particular to increase equity, for example by making a profit and good financial management.
\end{abstract}

Keywords: performance; negative equity; Altman Z-score; index IN05; Pearson correlation coefficient

\section{Introduction}

Equity is one of the business own resources of assets, which should be used in the business for a long time. The equity information is provided by the financial statements of a particular business, which in the case of double-entry accounting entities consists of a balance sheet, profit and loss account and notes and together provides a true and fair view of the business financial and revenue situation. The objective of financial statements is to present financial information that should primarily be understandable and comparable. The more comparable the accounting information, the better the explanatory power to users of that information. Through equity information, it is possible, among other things, to assess whether the business is financially sound or faces significant financial problems that may lead to the business demise in the future. Negative equity is one of the main indicators that apply when business is assessed as a business in crisis, apart from the low ratio of equity to liabilities and insolvency. Therefore, this paper deals with the impact of equity information on the business performance.

Proper assessment of the financial situation, especially the businesses performance is an important aspect of almost all economic decisions at the microeconomic and macroeconomic level, in the short and long term. The amount of financial and non-financial information currently available can sometimes make it difficult to evaluate the information available, which can lead to incorrect decisions. In the case of the shareholders' relationship with the business, from the point of view of their interest in achieving the value of their 
invested resources, it is relevant to correctly understand the dependencies of the business performance and the amount of equity. The aim of the quantitative research presented in the article is to identify the relationship between reported negative equity and the business performance in the Slovak Republic on an exhaustive sample of financial data of businesses with negative equity in the period 2014-2018. The paper is divided into 6 parts, in which the introduction is followed by a separate literature review, description of material and methods, results of discussion and conclusions of the research.

\section{Literature Review}

Performance is the ability of a business to obtain and manage resources in several different ways, which equates a competitive advantage [1,2]. In terms of financial management of the business, increasing the performance of businesses is one of the main goals of managers and can be evaluated by several indicators. The financial performance of a business includes the perception of a manager dealing with four financial areas, namely: improving the cost structure, expanding revenue opportunities, increasing the use of assets and increasing customer value [3]. The business performance is closely connected with the very existence of the business, as the performance increases the capital invested in the business, which increases the value of the business. High performance reflects a management efficiency and an efficiency in the use of business resources, which in a way contributes to the overall economy of the country [4]. At present, businesses are required to improve performance, mainly by increasing productivity, which can be measured by comparing outputs and inputs during the production process [5].

There are two types of performance, namely financial (economic) and non-financial (innovative) performance. The financial performance emphasizes variables that are directly related to the financial statements [6] and these variables include sales volume, profit level, return and revenue growth, return on investment, profitability growth, and market share [7]. The financial performance is the result of several individual decisions made by the management [8]. Innovative performance is generally expressed in terms of expenses, patents or percentages of innovative sales $[9,10]$. It is important that the innovative strategy that the business uses in the business is implemented in excellent business processes leading to customer satisfaction and improved financial performance [11]. Although economic and innovative performance are often closely linked [12], they are referred to in the literature as separate concepts or only one of them [13].

The improvement in overall financial performance is due to the development of better and more reliable relationships between socially responsible businesses and stakeholders such as employees, shareholders or customers [14-16]. To some extent, CSR is also associated with performance, the relationship of which has been examined by several authors who have concluded that companies developing CSR measures achieve better performance [17-20]. In addition, businesses dealing with CSR issues can gain recognition, which can improve access to finance, increase consumer demand, increase employee productivity and, at the same time, increase their value in the long term [21]. The concept of sustainable business, called green business or socially responsible business, is linked to a sustainable development. The sustainability and sustainable development have begun to be used to recognize that any uncontrollable growth, be it population, consumption, production and the like, is unsustainable in an environment of limited resources [22]. The basic precondition for sustainable development is the application of social responsibility by businesses that greatly influence the social, ecological and economical aspects of the society in which businesses operate [23]. The ability to integrate sustainability into corporate strategy and engage stakeholders is important in determining the financial situation of businesses in the 21st century [24].

In relation to the business performance, the key is especially the capital, with which the value of the business and the business wealth are closely connected, used in the business for a long time without the obligation to return it, i.e., own resources [25], which represent the difference between the amount of assets and liabilities in the broadest sense. Own 
resources exist in the company throughout the business and the company should always have them available, because they are long-term resources. In accounting, own resources are referred to as equity.

Equity can be divided into two basic parts in terms of the time of entry into the business [26]. The first part being the part that was invested in the business at its establishment, for example, the capital that was initially invested in the business by individual owners. The second part is related to the very period of existence and consists of internal resources (resources created by own activities), external resources (resources obtained by other owners' contributions to equity, such as gifts from partners) and resources acquired in another form (valuation differences arising from revaluation of some types of assets and liabilities in accordance with the Act on Accounting, share premium and others) [27]. The volume of equity plays a crucial role in determining the long-term survival of the business [28]. If the value of equity is negative, i.e., the amount of liabilities exceeds the amount of assets, the assets are financed mainly by foreign resources representing liabilities [29].

According to the previous characteristic, equity consists of several components, which in businesses in the Slovak Republic are reported in the financial statements in a formalized structure. The basic component of equity is the share capital, which is a monetary expression of the sum of monetary and non-monetary deposits made by all partners in the business. The share capital is compulsorily created in limited liability companies, joint stock companies and simple joint stock companies, while its amount is registered in the Commercial Register of the Slovak Republic [30]. In addition to the share capital, the components of equity also include capital funds, valuation differences, funds created from profit, profit or loss from previous years and profit or loss for the accounting period after tax. Accounting entities report all components of equity in the balance sheet on the liabilities side. Explanatory and additional information regarding changes in equity is included in the notes to the financial statements. The financial statements of accounting entities-businesses in the Slovak Republic are obligatorily published in the Register of Financial Statements of the Slovak Republic, which is freely available to users (without the obligation to register or pay a fee for its use) as an information source on the financial situation of accounting entities in the Slovak Republic.

\section{Measuring the Financial Performance of Businesses}

When evaluating the financial performance and predicting the future development of businesses, the relevant sources can be considered financial statements [31,32], which provide information for managers and a financial management, which can be included among the main tasks of the accounting system [33]. The annual report, which is a business performance monitoring tool, can also be considered a relevant source of information [34]. The content of the annual report is mandatory with disclosures required by legislation and voluntary disclosures [35]. Managers and a financial management belong to the internal users of information to whom comprehensive data is made available beyond the information required to be disclosed by law [36]. Conversely, external users, such as shareholders and various creditors, are used for decision-making only by published documents, including financial statements and annual reports. Managers and owners focus their attention on the business performance measured mainly by profit or distributed dividends [37]. In the case of a profit distribution, a situation may arise where the resources left in the business are not sufficient in the long run to cover the renewal of necessary fixed assets or purchase of inputs, which may cause that the business will not be able to maintain its main or productive capacity in the short term and will face bankruptcy in the future $[38,39]$. In identifying potential problems, the financial distress of a business and assessing financial stability, the information provided by the accounts is based, which should contain the correct and comprehensible information necessary for the financial analysis [40,41].

Financial analysis is used to assess the financial performance of businesses, which is considered a tool for diagnosing economic systems, while on the one hand helps to 
reveal the effects of economic and non-economic factors and on the other hand helps to estimate their future development [42]. Initially, the aim of the financial analysis was to assess the creditworthiness of the debtor by creditors [43]. Financial analysis is an integral part of the business financial management, providing feedback on where the business has reached in each area of financial management, in which areas the business has managed to meet its objectives and, conversely, in which areas the business did not meet the expected objectives. Financial analysis can be understood as an examination of economic phenomena or processes [44]. The main task of financial analysis is to report the property and financial situation of the business and at the same time to prepare documents relevant for the decision-making of managers in the internal environment. An enterprise that can consistently achieve the level of capital appreciation (profit rate, profitability) required by investors with respect to the amount of risk associated with the type of business can be considered as a financially sound or prospering enterprise. The opposite of financial health is financial distress, which is a situation where the business suffers from significant problems and the ability to repay liabilities is endangered [45]. This is primarily a situation where there is a reduction of own resources to negative values, which results in bankruptcy and termination of business.

Financial performance can be calculated through two categories of indicators. The first category consists of accounting-based indicators, such as return on equity (ROE), return on assets (ROA), return on sales (ROS), earnings per share (EPS), price-to-earnings ratio (P/E ratios), which are widely used [46-51]. The second category is market return indicators, such as market value (MV), price-to-income ratio (P/I ratio) and others [52,53].

It is the area of evaluation of information on negative equity and its impact on business performance that is not sufficiently examined in the literature, although critical situations are very important for long-term efficiency of business investment, so research results presented in this article are very important in the development of managerial information both in the scientific sphere and in practice.

\section{Materials and Methods}

The aim of the quantitative research carried out on a sample of economic information of businesses established in the Slovak Republic for the period of 2014-2018 is to assess the impact of a negative equity on the performance of the examined businesses. The quantitative research is carried out on a sample of businesses established in the Slovak Republic, whose financial statements in 2014-2018 are published in the register of financial statements, specifically in 2014 there were 181,153 businesses, in 2015 184,114 businesses analyzed, in 2016 we analyzed 191,240 businesses, in 2017 there were 201,075 businesses and in 2018 the most businesses were analyzed, namely 211,824. Businesses in bankruptcy or restructuring proceedings were excluded from the research sample, as they are already in the phase of closure and therefore it does not make sense to determine their future performance through historical data. At the same time, businesses for which reporting discrepancies were identified in the published financial statements were excluded and therefore are not a relevant basis for the analysis performed.

Among the data sources that are relevant for the research, we mainly include the financial statements of the examined businesses for the period of 2014-2018, which are published on the website of the register of financial statements maintained by the Ministry of Finance of the Slovak Republic [54], which is also publicly available to external users. An additional source of information is Finstat [55], which on a commercial basis regularly synchronizes information on businesses and data published in the register of financial statements, while in addition to the financial statements it provides more extensive and detailed structured information in tabular output formats.

From the information published in the financial statements of the examined businesses, we assessed the structure of equity of businesses for the period of 2014-2018. The basic descriptive statistics of the examined sample of businesses according to the amount of equity (E) and profit or loss after tax $(\mathrm{P} / \mathrm{L})$ in ' $000 €$ are in Table 1. 
Table 1. Descriptive statistics of a sample of businesses according to the amount of equity (E) and profit or loss after tax $(\mathrm{P} / \mathrm{L})$ in '000 €.

\begin{tabular}{ccccccc}
\hline & $\mathbf{2 0 1 4}$ & $\mathbf{2 0 1 5}$ & $\mathbf{2 0 1 6}$ & $\mathbf{2 0 1 7}$ & $\mathbf{2 0 1 8}$ & $\begin{array}{c}\text { For the Whole } \\
\text { Period }\end{array}$ \\
\hline Max. E & $6,720,921$ & $5,781,958$ & $4,550,000$ & $5,041,000$ & $5,613,000$ & $6,720,921$ \\
\hline Min. E & $-353,242$ & $-353,244$ & $-353,245$ & $-112,368$ & $-92,106$ & $-353,245$ \\
\hline Median E & 7 & 8 & 10 & 11 & 11 & 9 \\
\hline Average E & 451 & 456 & 420 & 422 & 417 & 432,452 \\
\hline Max. P/L & 813,397 & 664,000 & 462,989 & 645,000 & 119,884 & 813,397 \\
\hline Min. P/L & $-128,355$ & $-44,885$ & $-142,705$ & $-88,044$ & $-149,778$ & $-149,778$ \\
\hline Median P/L & 0.367 & 0.967 & 1 & 1 & 0.735 & 0.863 \\
\hline Average P/L & 33 & 42 & 36 & 38 & 20 & 33 \\
\hline
\end{tabular}

For research, we divided the businesses into three groups, i.e., businesses with a positive equity, negative equity and zero equity. Subsequently, we evaluated the performance of businesses reporting the negative equity in the period under review through bankruptcy and creditworthiness models, specifically the Altman's Z-score and the IN05 index. Based on the resulting values of these indicators, we have divided businesses into prosperous, non-prosperous and those for which we cannot determine with certainty whether they are prosperous or not. Using Pearson's correlation coefficient, we identify the relationship between the negative equity and the performance of the examined businesses. Subsequently, we compare selected models for evaluating the financial performance of businesses, while pointing out their strengths and weaknesses.

\section{Model and Data}

There are several models used to evaluate the business performance, two of which are relevant for research purposes, namely the Altman Z-score also known as the Altman financial health index and the IN05 index. Through Altman's Z-score, based on discriminatory analysis, Professor Altman sought to find indicators that are best able to distinguish between prosperous and non-prosperous businesses [56]. To determine the ratios that most faithfully characterize the financial and economic situation of businesses and especially for its future development, Professor Altman used a statistical method multiple discriminatory analysis consisting in finding the linear combination of indicators that best distinguishes a group of businesses into bankrupt and prosperous [57]. The calculation of the Altman Z-score (Z) is based on a formula in which it is necessary to determine the value of five unknown variables [58], from $x_{1}$ to $x_{5}$, according to formula 1 , which can be modified using these variables (2). The variable $x_{1}$ can be considered as a certain modification of liquidity ratios. The problem item is current assets, respectively their structure. If working capital is made up of unproductive and unsaleable assets, this can jeopardize the businesses profitability and solvency. The variable $\mathrm{x}_{2}$ expresses the rate of return on assets, regardless of the resources of financing. The variable $x_{3}$ representing the return on assets includes in the numerator the accounting profit, i.e., the profit before taxes and interest increased by interest expense reducing the accounting profit, through which it is possible to distinguish between different taxed and indebted businesses. Variable $\mathrm{x}_{4}$ assesses the indebtedness, with the numerator of this variable originally including the market value of equity, which was later replaced by Professor Altman for the book value of equity. The last variable $x_{5}$ expresses how the business values the invested funds.

$$
Z=0.717 * \frac{N W C}{T A}+0.847 * R O A+3.107 * \frac{E B I T}{T A}+0.42 * \frac{B V E}{F C}+0.998 * \frac{S}{T A}
$$

Explanations for a specific modification of the formula:

$\mathrm{x}_{1}$-the ratio of net working capital (NWC) and total assets (TA), 
$\mathrm{x}_{2}$-return on net assets (ROA),

$\mathrm{x}_{3}$-the ratio of earnings before interest and taxes (EBIT) and total assets (TA),

$\mathrm{x}_{4}$ - the ratio of book value of equity (BVE) and foreign capital (FC),

$\mathrm{x}_{5}$-ratio of sales (S) and total assets (TA).

Modified formula using variables:

$$
\mathrm{Z}=0.717 \mathrm{x}_{1}+0.847 \mathrm{x}_{2}+3.107 \mathrm{x}_{3}+0.42 \mathrm{x}_{4}+0.998 \mathrm{x}_{5}
$$

Based on the resulting value of the Altman Z-score, it is assessed whether the financial situation of the analyzed businesses is satisfactory, i.e., businesses are in the prosperity zone, or whether businesses have significant financial problems, i.e., they are in the bankruptcy zone, or businesses are in the gray zone, when it is not possible to clearly determine whether the business is prospering or not [59] (Figure 1).

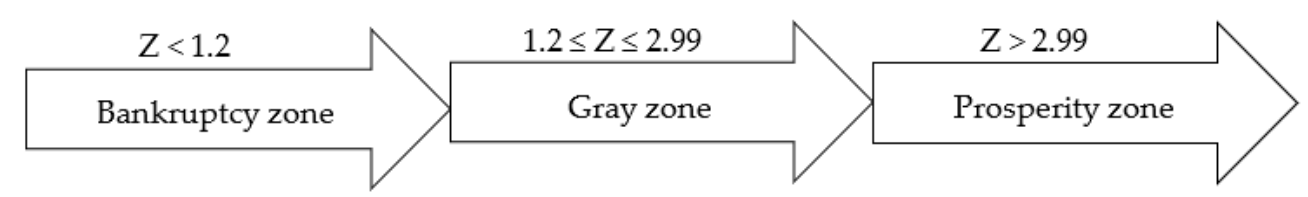

Figure 1. The resulting values of the Altman Z-score.

Index IN05 is the most famous Czech index created by the Mr. and Mrs. Neumaier, which allows the evaluator to express a comprehensive conclusion about the business performance. Although the IN05 index was created for the conditions of businesses established in the Czech Republic, it can be applied to businesses established in the Slovak Republic, as the items in the reports are similar in the Czech and Slovak Republics, which means that all information needed to the calculation of the IN05 index can be found in the balance sheets and statements of businesses also in the conditions of the Slovak Republic [60]. The following items (3) are used in the calculation of the IN05 index [61]: total assets (TA), foreign capital (FC) profit before interest and taxes (EBIT), interest expense (IE), total revenues (TR), current total assets (CTA) and current liabilities (CL), which can also be modified using variables $\mathrm{y}_{1}$ to $\mathrm{y}_{5}(4)$.

$$
I N 05=0.13 * \frac{T A}{F C}+0.04 * \frac{E B I T}{I E}+3.97 * \frac{E B I T}{T A}+0.21 * \frac{T R}{T A}+0.09 * \frac{C T A}{C L}
$$

Explanations for a specific modification of the formula:

$\mathrm{y}_{1}$-ratio of total assets (TA) and foreign capital (FC),

$\mathrm{y}_{2}-$ ratio of earnings before interest and taxes (EBIT) and interest expense (IE),

$\mathrm{y}_{3}-$ ratio of earnings before interest and taxes (EBIT) and total assets (TA),

$\mathrm{y}_{4}$-ratio of total revenues (TR) and total assets (TA),

$\mathrm{y}_{5}$-ratio of current total assets (CTA) and current liabilities (CL).

Modified formula using variables:

$$
\mathrm{IN} 05=0.13 \mathrm{y}_{1}+0.04 \mathrm{y}_{2}+3.97 \mathrm{y}_{3}+0.21 \mathrm{y}_{4}+0.09 \mathrm{y}_{5}
$$

As with the Altman Z-score, the IN05 index also assesses, on the basis of the resulting value, whether businesses create value, i.e., are creditworthy, or whether they are bankrupt or are in the gray zone [60] (Figure 2). 


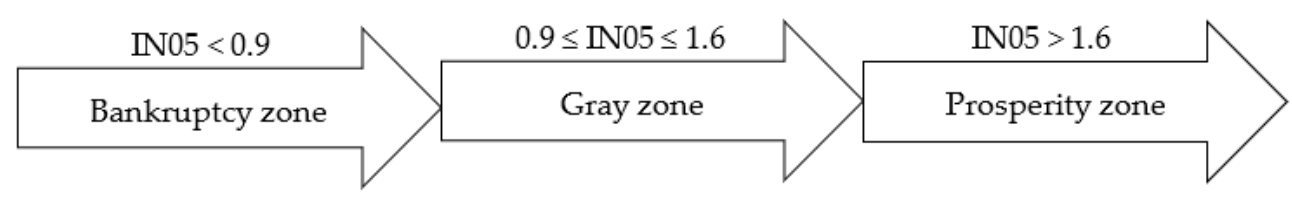

Figure 2. The resulting values of the IN05 index.

We apply both models on the same database of businesses in Slovakia with aim to compare the results of the classification of businesses into three zones describing the stability of businesses. Using Pearson's correlation coefficient, we subsequently identified the interdependence between negative equity and the financial performance of businesses based on the calculation of the Altman Z score and the IN05 Index. Pearson's correlation coefficient is currently considered to be the most important and most used correlation coefficient, the calculation of which is realized from $n$ pair values $\left(\mathrm{x}_{\mathrm{i}}, \mathrm{y}_{\mathrm{i}}\right)$, while the sampling of Pearson's correlation coefficient $r(X, Y)$ is considered to be an estimate of its theoretical value [62] (5), which can take different values from the interval $<-1 ; 1>$ [63] explained in Table 2.

$$
r(X Y)=\frac{s(X, Y)}{s(X), s(Y)}
$$

Table 2. Characteristics of Pearson correlation coefficient values.

\begin{tabular}{cc}
\hline The Value of the Correlation Coefficient & Interpretation \\
\hline $0.90-1.00(-1.00$ to -0.90$)$ & very high correlation \\
\hline $0.70-0.90(-0.90$ to -0.70$)$ & high correlation \\
\hline $0.50-0.70(-0.70$ to -0.90$)$ & medium correlation \\
\hline $0.30-0.50(-0.50$ to -0.30$)$ & low correlation \\
\hline $0.00-0.30(-0.30$ to 0.00$)$ & very low or no correlation \\
\hline
\end{tabular}

If the values of the correlation coefficient are higher than zero, we speak of a positive correlation, in the opposite situation, when the correlation coefficient acquires values lower than zero, we speak of a negative correlation. The absolute values of the Pearson correlation coefficient express the strength of the correlation of the investigated variables and the signs express the character of the correlation, i.e., whether it is a direct or indirect dependence between the variables.

\section{Results}

The equity structure of businesses established in the Slovak Republic was different in the period of 2014-2018, with a positive equity prevailing over the entire period under review, which averages $68 \%$ of businesses, which corresponds to an average of 131,805 businesses. On average, $29 \%$ of businesses have a negative equity, which corresponds to an average of 56,742 . The remaining businesses (on average $3 \%$ ) show zero equity, namely an average of 5335 businesses. Based on the analysis, it can be assessed that with each passing year there is an increase in the number of businesses with a positive equity and a decrease in businesses with a negative equity. It follows from the above that in 2018 the least businesses had a negative equity (Figure 3). Of the examined businesses for the whole monitored period, the profit shows an average of $57 \%$ (110,512 businesses), the loss shows an average of $38 \%$ (73,675 businesses and the rest of the businesses, on average $5 \%$ (9694) shows an economic result equal to zero. It follows from the above that during the period considered more businesses with a positive equity predominate over profitable businesses (Figure 3). 


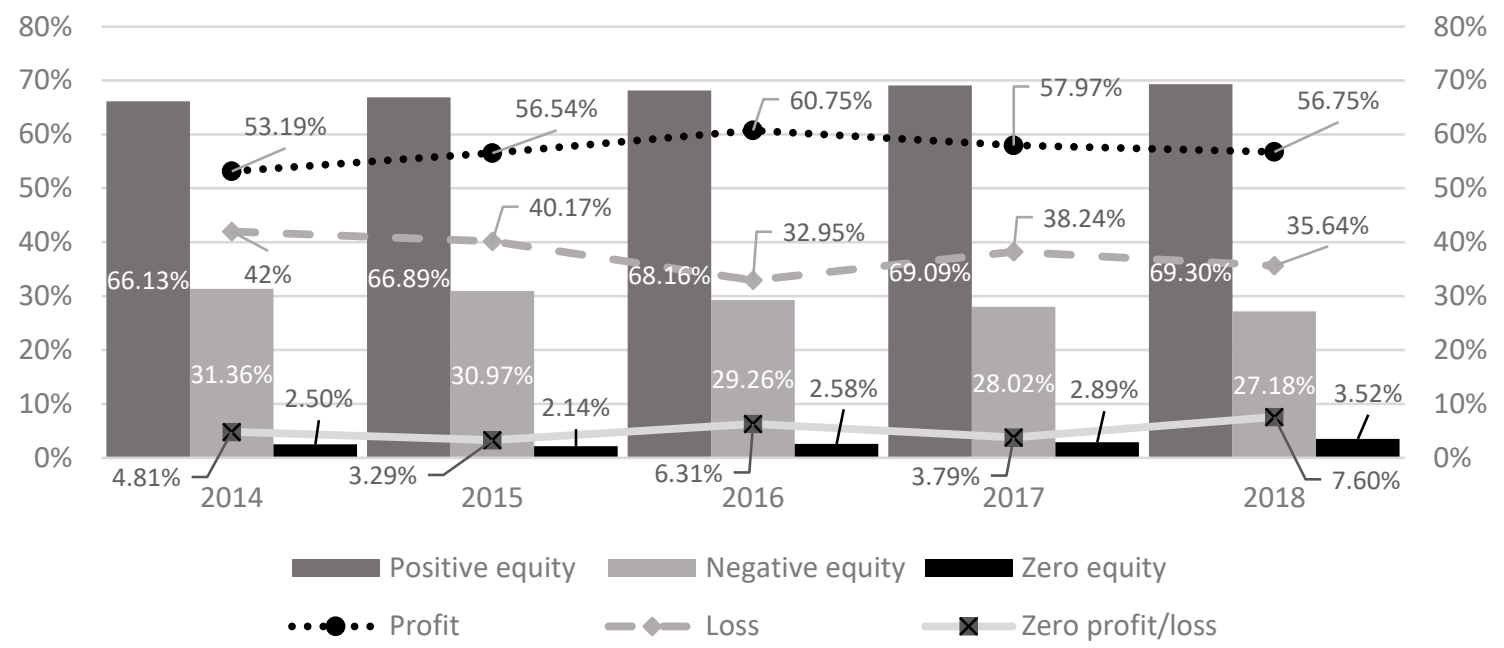

Figure 3. The structure of the examined sample of businesses according to the value of equity and profit or loss after tax in the monitored period.

We further performed a deeper analysis on a group of businesses with a negative equity. The average value of a negative equity fluctuated during the monitored periods, while in 2014-2017 its value decreased and since 2018 it increased by $€ 2305$. The amount of an average negative equity is partly influenced by the amount of average profit or loss after tax, which had the character of a loss during the period under review with an average amount of $€-28,292$. However, the amount of the loss was not very significant, as it averaged $20 \%$ of a negative equity (Figure 4 ).

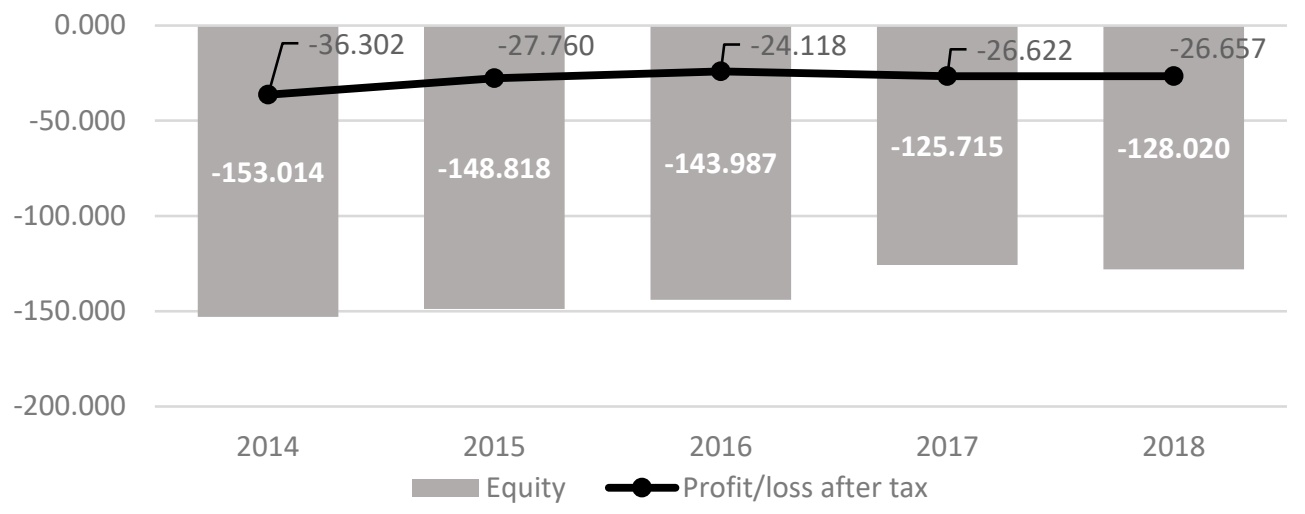

Figure 4. Development of the average amount of a negative equity and profit or loss after tax.

\subsection{Analysis of Equity and Performance of Businesses According to Altman's Z-Score}

The results of the Altman Z-score showed that from the examined businesses, which had a negative equity between 2014 and 2018, on average 69\% (39,182 businesses) are in bankruptcy, i.e., these businesses have significant financial problems. On average, $18 \%$ of businesses with a negative equity in the period under review are in the prosperity zone. This percentage corresponds to an average of 10,066 businesses. On average, 13\% (7494 businesses) are in the gray zone, which means that it is not clear whether they have a satisfactory financial situation or are facing significant financial problems. In 2018, most businesses are in the bankruptcy zone, namely 70.73\% (7150 businesses) (Figure 5). 


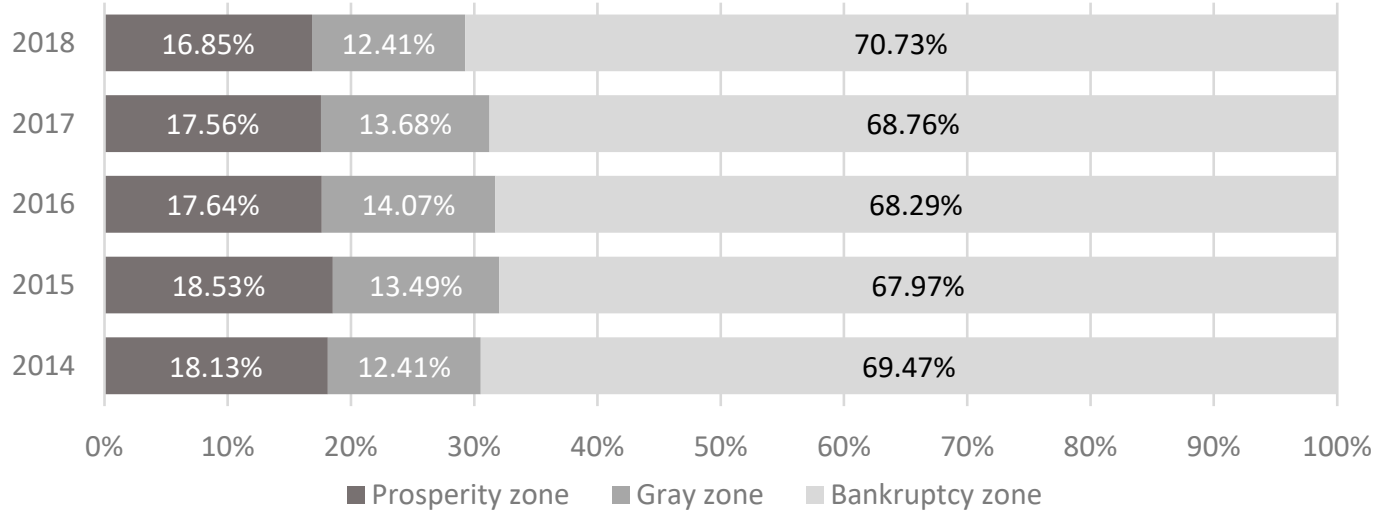

Figure 5. Financial performance of businesses with negative equity based on Altman's Z-score.

Given that the evaluation of the development of financial performance by means of the Altman Z-score was carried out on businesses with a negative equity, it is necessary to examine the development of individual variables used to calculate the Altman Z-score. The average value of the variable $x_{1}$, which is the ratio of net working capital to total assets, acquired negative values during the whole monitored period, but did not have a significant impact on business performance, due to its negative nature and lowest absolute value in the whole examined period (Figure 6). The variable $x_{2}$ represents the ratio of accounting profit to total assets, often referred to as the return on assets. Businesses that generated negative equity in previous accounting periods and made a profit during the period under review, thereby which their negative equity decreases in absolute terms, may still report a negative equity in the period under review, which is the case for variable $\mathrm{x}_{2}$. It follows from the above that given that the average value of the variable $x_{2}$ is positive in the monitored periods, the financial situation in the businesses concerned is improving. The situation is similar for variable $\mathrm{x}_{3}$, which is the ratio of profit before interest and taxes to total assets, and at the same time variable $x_{5}$, which is the ratio of sales and total assets. The average value of the variable $x_{4}$ representing the ratio of equity to foreign capital is negative in the monitored periods, given that the subject of the analysis were businesses reporting the negative equity. This fact did not have an absolute impact on the performance of the examined businesses, as in the case of the Altman Z-score, in addition to equity, other items and coefficients expressing the weight of the relevant indicators $x_{1}$ to $x_{5}$ are taken into formula (Figure 6).

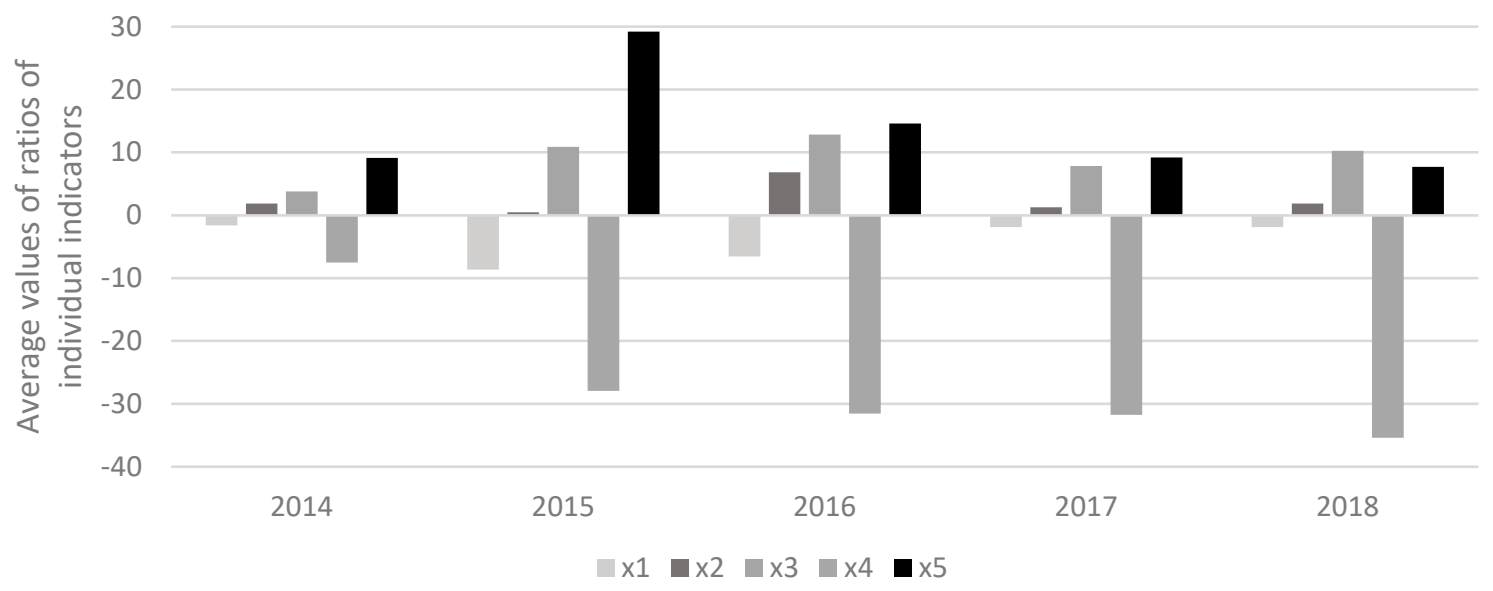

Figure 6. Average values of Altman Z-score variables. 
Based on Pearson's correlation analysis of businesses in individual groups of businesses classified according to the Altman Z score in the bankruptcy, gray and prosperity zones, we found the following dependencies. Businesses that showed negative equity in the period under review can be found to have a high positive correlation between negative equity and the bankruptcy zone. The value of the Pearson correlation coefficient between the stated items corresponded to 0.88 , which shows a high positive correlation. It follows that if businesses are in a bankruptcy zone, negative equity may adversely affect their existence, as there is a threat of a lack of own resources to meet their liabilities. The value of the Pearson correlation coefficient in the case of negative equity and the gray zone is equal to -0.70 , which is the threshold value between medium and high negative correlation. As the value of the businesses' negative equity in the gray zone decreases, the value of the Altman Z-score increases linearly, which means an improvement in the business financial situation. From the above, it can be said that in businesses located in the gray zone, higher negative equity may also negatively affect their operation. Although it is uncertain in the gray area whether businesses are prosperous or not, if they show a negative equity in the long time and its value increases, may threaten to enter the bankruptcy phase sooner. There is minimal dependence between the negative equity and the prosperity zone, from which it can be concluded that the negative equity will not significantly affect prosperous businesses. The value of the Pearson correlation coefficient between the mentioned elements corresponded to 0.08 . The results are also confirmed by the graphical dependence, where an almost linear course of the negative equity and the bankruptcy zone and at the same time a different course of the prosperity zone and the gray zone can be seen (Figure 7).

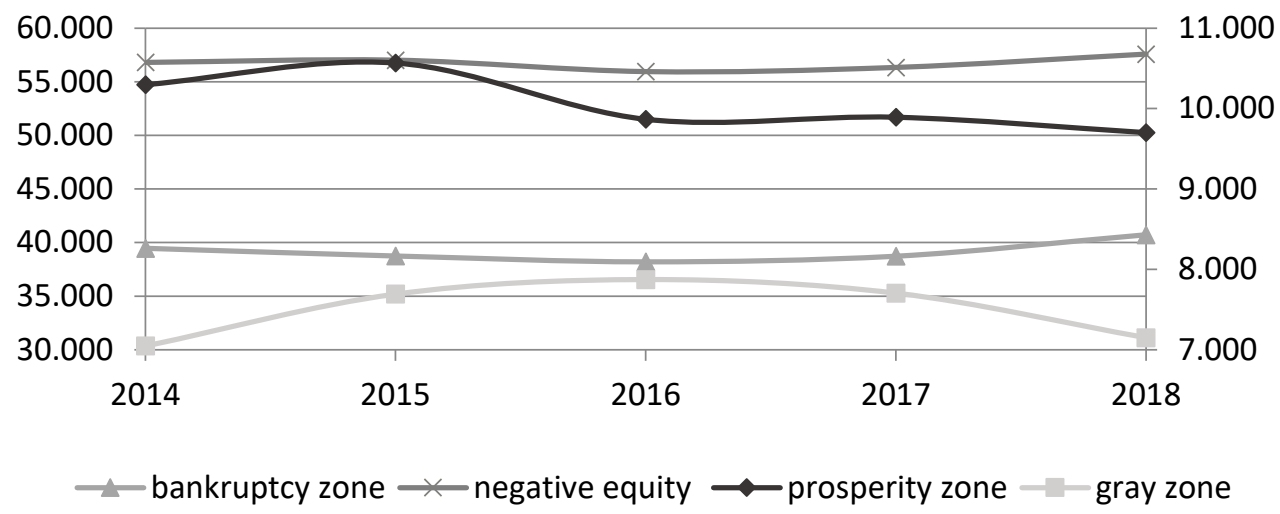

Figure 7. The relationship between a negative equity and a performance examined according to Altman's Z-score.

\subsection{Analysis of Equity and Performance of Businesses According to the IN05 Index}

Based on the IN05 index, it can be stated that on average $66 \%$ of businesses in the Slovak Republic reporting a negative equity in the period of 2014-2018 face significant financial problems, i.e., they are in a bankruptcy zone. This percentage corresponds to an average of 37,464 businesses. On average, $19 \%$ (10,847 businesses) are in the prosperity zone, so it can be stated that these businesses form a certain value in the monitored period. For the remaining businesses, which average $15 \%$ (8432 businesses), we cannot determine with certainty whether they are prosperous or not, as they are in the gray zone. The number of businesses in the bankruptcy zone decreased every year, while in 2018 their number increased by less than $1 \%$ compared to 2017 (Figure 8). 


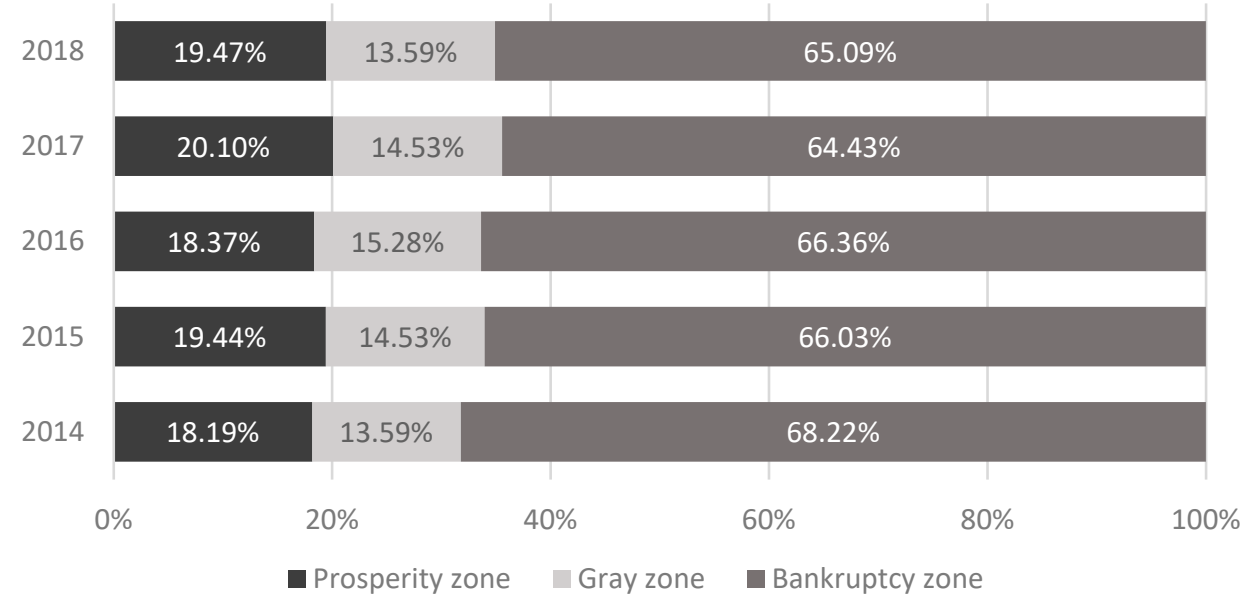

Figure 8. Financial performance of businesses with a negative equity based on IN05 index.

As with the Altman Z-score, the IN05 index also needs to examine the individual variables used to calculate it, as the analysis of financial performance was examined only in the case of businesses with a negative equity in the period under review. Based on the variable $y_{1}$, we analyze the ratio of total assets to foreign resources, respectively how many units of assets represent one unit of liabilities. The average value of this variable during the monitored periods ranges from 0 to 1 . The variable $y_{2}$ represents the ratio of profit before taxes and interest expense, which is known as interest coverage. This indicator indicates how many times the total profit will cover interest payments, and the higher the value of the indicator, the higher its ability to pay the costs related to the use of a foreign capital. The average values of the mentioned indicator in the case of the analyzed businesses for the whole monitored period were negative, which means that analyzed businesses are not able to cover the costs associated with the foreign capital. The variable $y_{3}$ in the case of the index IN05 is identical to the variable $x_{3}$ in the Altman Z-score and represents the ratio of earnings before interest and taxes to total assets. As it is the same variable, its values are the same in both used models of financial performance and acquire positive values during the monitored periods. The penultimate variable $\mathrm{y}_{4}$ represents the ratio of total income to total assets and expresses how many units of income one unit of assets makes up. The turnover of assets depends mainly on the sector in which the business operates, for example, if we compare the industries and sectors in which services predominate, in the case of the industry businesses with a large asset base have, as a result services where it is not necessary to dispose of a high proportion of assets [37]. Although the examined businesses operate in various sectors, in the monitored periods the indicator of the ratio of total revenues and total assets acquired positive values. The last variable $y_{5}$ is the ratio of total current assets to current liabilities, which expresses how many units of current assets make up one unit of current liabilities. The average values of this variable acquired positive numbers during the monitored periods (Figure 9). Although the variables $\mathrm{y}_{1}, \mathrm{y}_{3}, \mathrm{y}_{4}$ and $\mathrm{y}_{5}$ acquired positive values, the average value of the variable $y_{2}$ significantly exceeded them, so if we analyzed the index IN05 only through the average values of individual variables, the examined businesses with negative equity would be in bankruptcy zone or in the gray zone. In the case of the analysis of individual variables from index IN05 separately for each business, a situation arises where businesses with a negative equity create value or are in the zone of prosperity. 


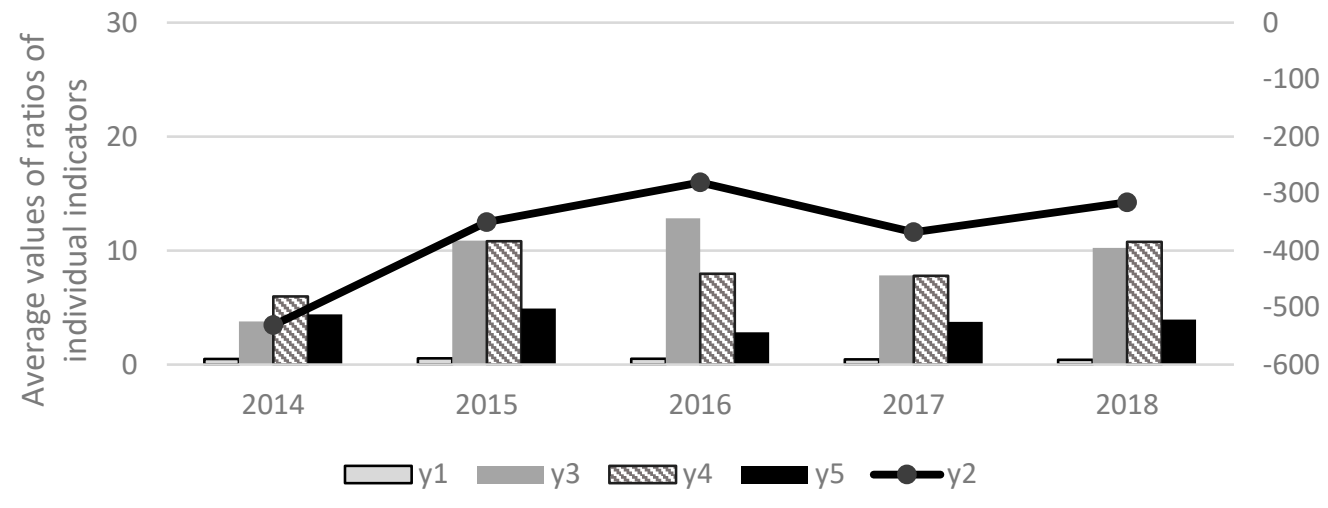

Figure 9. Average values of IN05 index

Pearson's correlation analysis carried out between the negative equity and the business performance calculated according the IN05 index showed a low correlation between the negative equity and the prosperity zone, as well as the negative equity and the bankruptcy zone. In both cases, the value of the Pearson correlation coefficient ranged from 0.30 to 0.50 , specifically in the case of the negative equity and prosperity zone, the Pearson correlation coefficient reached 0.47 , and in the case of the negative equity and bankruptcy zone, its value was 0.40 . Based on the above results, it can be stated that in the case of analyzing the financial performance of business according to the IN05 index, a negative equity will not have an impact on either prosperous business or those leading to bankruptcy. The fact that the IN05 index does not use the value of equity as in the case of the Altman Z-score also contributes to this statement. In the case of the analysis of the negative equity and the gray zone, the value of the Pearson correlation coefficient was equal to 0.08 , which means a very low correlation, and thus the negative equity has no effect on business located in the gray zone (Figure 10).

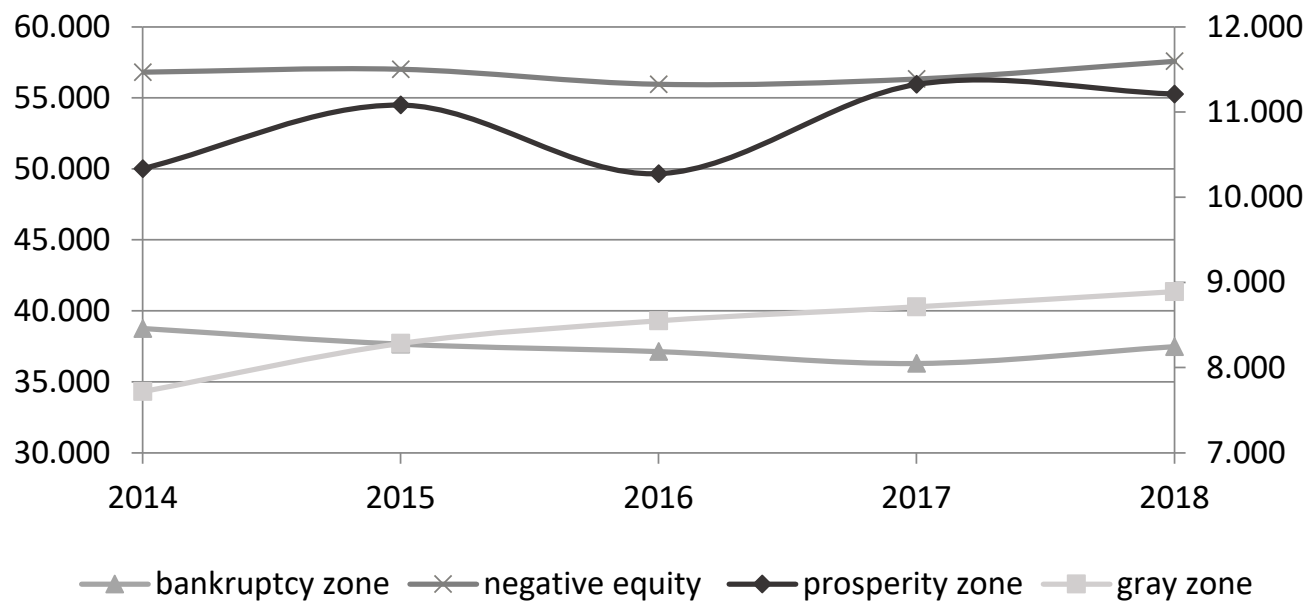

Figure 10. The relationship between the negative equity and the performance examined according to IN05 index.

\subsection{Comparison of Altman Z-Score and IN05 Index}

Based on both selected models of evaluating the financial performance of businesses, it can be stated that businesses with a negative equity are in all three zones of performance evaluation, with most of them in the zone of bankruptcy. While in the case of the Altman Z-score, on average $69 \%$ of businesses are in the bankruptcy zone, in the case of the IN05 index, on average $66 \%$ of businesses are in the bankruptcy zone. Based on the results of the Altman Z-score, an average of $18 \%$ of businesses are in the prosperity zone, which 
is $1 \%$ less than in the case of the IN05 index, where an average of $19 \%$ of businesses are prosperous. The results are also similar for the gray zone, with the Altman Z-score being on average $13 \%$ of businesses in the gray zone and the IN05 index averaging $15 \%$ of businesses. The results differ in the case of a separate comparison of years, for example in the case of 2018, when the bankruptcy zone in the case of Alt-man's Z-score is the largest number of businesses, namely 70.73\%, while in the case of IN05 index 65.09\% are bankrupt in 2018 . (Figure 11).

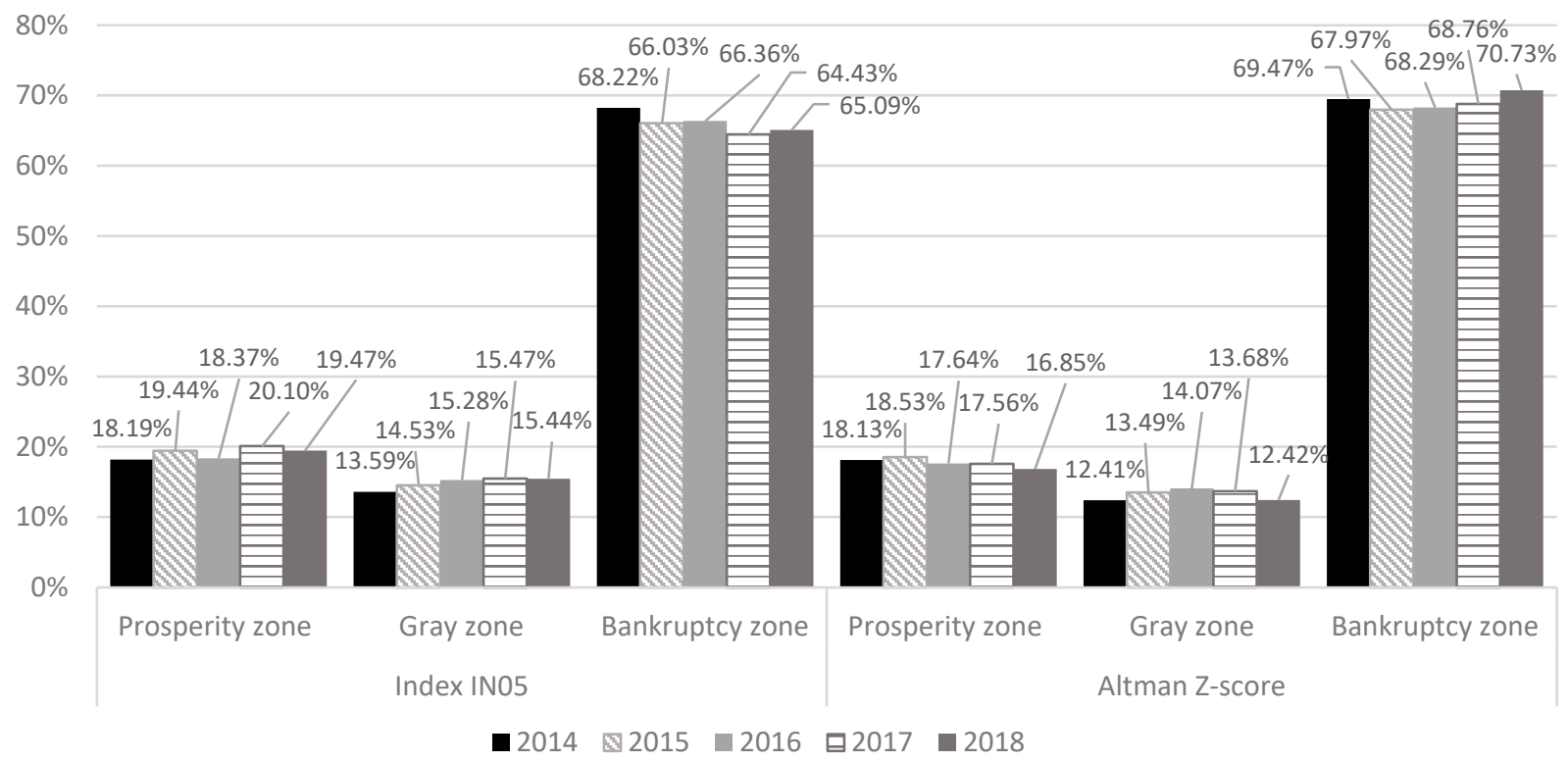

Figure 11. Comparison of financial performance results calculated using Altman's Z-score and IN05 index.

From the point of view of determining the dependence based on the calculation of the Pearson correlation coefficient for individual models, an important aspect is the use of the equity value indicator in Altman's Z-score and IN 05. In IN05 calculation, equity is not included and therefore the dependence of this indicator on the value of the negative equity in any zone (prosperity, gray, bankruptcy) is not confirmed. In the Altman Z-score, the determination of the dependence of the value of the negative equity was relevant, because a strong direct dependence (correlation coefficient 0.88 ) in the bankruptcy zone, a weaker indirect dependence in the gray zone (correlation coefficient -0.7) and almost no negative visibility in the prosperity zone.

\section{Discussion}

The prediction of bankruptcy or the prediction of financial distress has been a muchdiscussed topic in various countries around the world for several decades $[64,65]$ and at the same time it is an essential and widely studied topic [66,67], which is receiving special attention [68]. Due to the instability of the economic environment, costs increase, and certain problems arise both for businesses and other parties, which are dependent either directly or indirectly on the activities or the very existence of these businesses, so it is for these stakeholders (business owners, potential investors, management, employees, creditors, government and others) important to monitor whether business is at risk of bankruptcy or not [69].

In the comparison of both models, it can be said that they belong to the most wellknown bankruptcy and creditworthiness models used in assessing the financial situation of businesses. Altman's Z-score is based on a comparison and analysis of financial data of bankrupt and non-bankrupt businesses. Altman's Z-score represents an opportunity to evaluate the overall financial health of the business through a single number, the so-called Z-score. The advantages of the Altman Z-score include easy applicability and the success 
of bankruptcy prediction about two years before it took place [70]. The main disadvantage is its focus on industrial businesses. Nevertheless, its accuracy is sufficient [71].

The advantages of the IN05 index include a simple calculation, as the algorithms of the financial indicators represented in this model are transparent. At the same time, the model works with publicly available financial data for the business in the conditions of Slovakia, as well as the Czech Republic, the model can be used for businesses tradable and non-tradable on the capital market. The advantage of the IN05 index is also the unambiguity of the results, and therefore it is suitable for use as a supplement to other indicators [72]. It is also appropriate to use this model as part of various economic analyzes of the business situation, as it removes subjectivity in the selection of indicators and their significance. It is important to mention that using the IN05 index it is possible to assess business performance from two perspectives, namely from the creditor's point of view such as the threat of bankruptcy and from the point of view of ownership, including value creation. The disadvantage is that it combines the state of the business into one number, which prevents the identification of the area in which the business has problems, thus making it impossible to identify options for eliminating these problems. Although the IN05 index has excellent significance, it should be borne in mind that it is only a rough guide to estimate the overall performance of the business, but the IN05 index alone does not provide a detailed view of how this performance has been achieved [73].

The results of the analysis carried out on businesses established in Slovakia during 2014-2018 using two models for measuring financial performance show that in the case of Altman's Z-score, negative equity has a negative impact on businesses in the bankruptcy zone. Conversely, in the case of the IN05 index, where a low correlation between the negative equity and the zone of prosperity or bankruptcy has been identified, the negative equity will not have a negative impact on businesses located in these zones. Although we analyzed the financial performance only in businesses with a negative equity in the monitored periods, the results showed that these businesses include not only non-prosperous businesses and those for which we cannot determine with certainty whether they are prosperous or not, but also prosperous businesses. This is mainly because that several variables are used in the selected indicators for measuring financial performance. Altman's Z-score uses, among other things, the book value of equity, while in the index IN05 we do not find a single variable that deals with equity. For this reason, it would be appropriate to replace one of the variables in index IN05, for example the variable $\mathrm{y}_{2}$ having the least weight, representing the ratio of profit before tax and interest, and to replace interest expenses with a variable showing changes in equity items due to distribution of profit or arrangement of loss of the previous accounting period [37], which will be the subject of further research. At the same time, the subject of the research will be a detailed analysis of the items needed to calculate the variables in both models as well as detailed equity items and their impact on business performance.

\section{Conclusions}

Equity is one of the business own resources available for a long time. From an accounting point of view, equity is the difference between assets and liabilities. The most important component of equity is the share capital, which is the sum of cash and non-cash contributions of all shareholders to the company. The share capital in the Slovak Republic must be created by limited liability companies in the amount of at least $€ 5000$, joint-stock companies in the minimum amount of $€ 25,000$ and simple companies for shares in the amount of at least $€ 1$. The share capital of the cooperative consists of a total of membership fees and its amount is at least $€ 1250$. The limited partnership does not directly follow from the Commercial Code the obligation to create share capital, but it sets a minimum amount of the limited partnership's contribution in the amount of $€ 250$ [30]. In addition to the share capital, the equity of business accounting entities consists of capital funds, valuation differences, funds created from profit, profit or loss for previous years and profit or loss for the accounting period after tax. If the equity reaches a negative value, it means that the 
amount of liabilities exceeds the amount of assets, or that the businesses assets are financed mainly through external resources representing liabilities. At present, a negative equity is a common phenomenon encountered by many businesses.

The aim of the article was to assess the impact of a negative equity on the performance of businesses established in the Slovak Republic for the period of 2014-2018 via two models of the financial performance evaluation, namely the Altman Z-score and the IN05 index. The subject of the research was all businesses operating during 2014-2018 in Slovakia, from which we excluded businesses in bankruptcy or restructuring proceedings as well as businesses for which we identified inconsistencies in reporting. Based on descriptive business statistics, we identified the maximum, minimum, average value and median of equity and profit after tax. The analysis shows that throughout the period under review, on average $68 \%(131,805)$ of businesses have positive equity, an average of $29 \%(56,742)$ of businesses have negative equity and an average of $3 \%$ (5335) of businesses have zero equity. Throughout the period under review, an average of 57\% $(110,512)$ of businesses reported a profit, an average of $38 \%(73,765)$ of businesses reported a loss and an average of $5 \%$ (9694) of businesses reported a zero profit.

The results of the Altman Z-score showed that in the monitored period, on average, $69 \%$ of $(39,182)$ businesses with the negative equity are in bankruptcy, which means that these businesses have significant financial problems. At the same time, it can be stated that on average $18 \%(10,066)$ of businesses with the negative equity are in the zone of prosperity, and thus, despite showing negative equity, they are prosperous. The remaining businesses, on average $13 \%$ (7494), are in the gray area, so we cannot say with certainty whether they are prosperous or not. Similar results were shown by the second model, the IN05 index, where on average $66 \%(37,464)$ of businesses face significant financial problems, on average $19 \%(10,847)$ of businesses are in the prosperity zone and for the remaining businesses, on average $15 \%$ (8432) we cannot determine whether they are prosperous or heading for bankruptcy, as they are in the gray zone.

Based on Pearson's correlation analysis, it can be stated that in the case of assessing the financial performance of businesses according to the Altman Z-score, there is a high positive correlation between negative equity and the bankruptcy zone (0.88), i.e., negative equity has a significant impact on the performance of businesses in the bankruptcy zone and at the same time on their existence. A Pearson correlation coefficient of -0.70 was identified between the negative equity and the gray zone, which is the cut-off value for the medium and high negative correlations. It follows that, even in the case of businesses located in the gray zone, the negative equity may adversely affect their performance, while as the absolute value of the negative equity increases, the businesses performance decreases. On the contrary, as the absolute value of equity decreases, the performance of businesses increases. There is a low correlation between the negative equity and the prosperity zone (0.08), so the negative equity will not affect the performance of businesses in this zone. In the case of the performance evaluation according to the IN05 index, a low correlation can be identified between the negative equity and the prosperity zone (0.47), as well as between the negative equity and the bankruptcy zone (0.40). It follows from the above that the negative equity will not have a significant impact on prosperous and bankrupt businesses, which may be because that the IN05 index does not use the value of the equity, as in the case of the Altman Z-score. There is a very low correlation between the negative equity and the gray zone (0.08), so the negative equity will not affect businesses in the gray zone.

The models used in the analysis are among the most used in assessing the financial situation of the business and can be applied to conditions in the Slovak Republic and the Czech Republic. It is appropriate that both models be used in conjunction with other indicators to assess the financial situation of the business which responsibly determines the current situation and position of the business and to identify areas where the business has problems causing its poor financial health, and at the same time propose measures to address and eliminate these problems [60]. 
Based on the results of the analysis, it can be said that the examined businesses, which show negative equity during the monitored period 2014-2018, according to Altman's Z-score and IN05 index are in all three zones, i.e., in the zone of prosperity, bankruptcy, but also in the gray zone, while most businesses are in the zone of bankruptcy, specifically when using the Altman Z-score it is on average $69 \%(39,182)$ of businesses and in the index IN05 it is on average $66 \%(37,464)$ of businesses. Although these businesses with negative equity are in bankruptcy, they do not have to automatically terminate their activities. On the contrary, they should look for ways to improve their financial situation. The best solution for these businesses is to increase their equity by making a profit in the following accounting periods, when businesses can quickly reach the zone of prosperity, which we confirmed in the research. The same should be done for businesses with negative equity located according to the Altman Z-score and the IN05 index in the gray zone, namely an average of $13 \%$ (7494) of businesses according to the Altman Z-score and an average of $15 \%$ (8432) of businesses according to the IN05 index. Given that we cannot determine with certainty whether these businesses are prosperous or not, their object should be to strive for prosperity, which means that they should seek to increase their equity, with the best solution being as in the case of businesses in the bankruptcy zone, making a profit in subsequent accounting periods. Making a profit is the most important goal of all business accounting entities. Another way to improve the financial situation and bridge the period of crisis caused by external factors, such as the mortgage crisis, global pandemic situation or natural resource crisis, can be the use of innovative performance.

Author Contributions: Conceptualization, K.T. and R.P.; data curation, K.T.; formal analysis, K.T. and R.P.; investigation, K.T.; methodology, K.T. and R.P.; resources, K.T.; supervision, R.P.; validation, K.T. and R.P.; visualization, K.T. and R.P.; writing—original draft, K.T. and R.P.; writing—review \& editing, K.T. and R.P. All authors have read and agreed to the published version of the manuscript.

Funding: This research received no external funding.

Acknowledgments: This article is an output of the projects APVV-16-0602 and I-20-109-00.

Conflicts of Interest: The authors declare no conflict of interest. The funders had no role in the design of the study; in the collection, analyses, or interpretation of data; in the writing of the manuscript, or in the decision to publish the results.

\section{References}

1. Iswatia, S.; Anshoria, M. The Influence of Intellectual Capital to Financial Performance at Insurance Companies in Jakarta Stock Exchange (JSE). In Proceedings of the 13th Asia Pacific Management Conference, Melbourne, VIC, Australia, 18-20 November 2007; pp. 1393-1399.

2. Yudhanti, C.B.H.; Shanti, C.J. Intellectual Capital dan Ukuran Fundamental Kinerja Keuangan Perusahaan. J. Akut. dan Keuan. 2011, 13, 57-66. [CrossRef]

3. Kaplan, R.S.; Norton, D.P. Strategy Maps: Converting Intangible Assets into Tangible Outcomes; Harvard Business School Press: Boston, MA, USA, 2004.

4. Naser, K.; Mokhtar, M. Determinants of Corporate Performance of Malaysian Companies. In Proceedings of the Fourth Asia Pacific Interdisciplinary Research in Accounting Conference, Singapore, 4-6 July 2004.

5. Endiana, I.D.M.; Dicriyani, N.L.G.M.; Adiyadnya, M.S.P.; Putra, I.P.M.J.S. The Effect of Green Accounting on Corporate Sustainability and Financial Performance. J. Asian Financ. Econ. Bus. 2020, 2, 731-738. [CrossRef]

6. Almajali, Y.A.; Alamro, S.H.; Al-Soub, Y.Z. Factors Affecting the Financial Performance of Jordanian Insurance Companies Listed at Amman Stock Exchange. J. Manag. Res. 2012, 4, 266-289. [CrossRef]

7. Donkor, J.; Donkor, G.N.A.; Kankam-Kwarteng, C.; Aidoo, E. Innovative capability, strategic goals and financial performance of SMEs in Ghana. Asia Pac. J. Innov. Entrep. 2018, 12, 238-254. [CrossRef]

8. Epstein, M.J.; Buhovac, A.R.; Yuthas, K. Managing Social, Environmental and Financial Performance Simultaneously. Long Range Plan. 2015, 48, 35-45. [CrossRef]

9. Oerlemans, L.; Meeus, H. Do organizational and spatial proximity impact on firm performance? Reg. Stud. 2010, 39, 89-104. [CrossRef]

10. Hagedoorn, J.; Cloodt, M. Measuring innovative performance: Is there an advantage in using multiple indicators? Res. Policy 2003, 32, 1365-1379. [CrossRef]

11. Soewarno, N.; Tjahjadi, B. Eco-oriented culture and financial performance: Roles of innovation strategy and eco-oriented continuos improvement in manufacturing state-owned enterprises, Indonesia. Enterp. Sustain. Issues 2020, 8, 341-359. 
12. Damanpour, F.; Evan, W.M. Organizational Innovation and Performance: The Problem of "Organizational Lag". Admin. Sci. Q. 1984, 29, 392-409. [CrossRef]

13. Knoben, J.; Oerlemans, L. The effects of firm relocation on firm performance-A literature review. Europ. Reg. Sc. Ass. 2005, 1-25.

14. Davis, K. The case for and against business assumption of social responsibilities. Acad. Manag. J. 1973, 16, 312-322.

15. Chen, H.; Wang, X. Corporate social responsibility and corporate financial performance in China: An empirical research from Chinese firms. Corp. Gov. Int. J. Bus. Soc. 2011, 11, 361-370. [CrossRef]

16. Turban, D.B.; Greening, D.W. Corporate social performance and organizational attractiveness to prospective employees. Acad. Manag. J. 1997, 40, 658-672.

17. Lorraine, N.H.J.; Collison, D.J.; Power, D.M. An analysis of the stock market impact of environmental performance information. Account. Forum 2004, 28, 7-26. [CrossRef]

18. Pivato, S.; Misani, N.; Tencati, A. The impact of corporate social responsibility on consumer trust: The case of organic food. Bus. Ethics A Eur. Rev. 2008, 17, 3-12. [CrossRef]

19. Hou, T.C.-T. The relationship between corporate social responsibility and sustainable financial performance: Firm-level evidence from Taiwan. Corp. Soc. Responsib. Environ. Manag. 2019, 26, 19-28. [CrossRef]

20. Orlitzky, M.; Schmidt, F.L.; Rynes, S.L. Corporate social and financial performance: A meta-analysis. Organ. Stud. 2003, 24, 403-441. [CrossRef]

21. Munoz, R.M.; Fernandez, M.V.; Salinero, Y. Sustainability, Corporate Social Responsibility, and Performance in the Spanish Wine sector. Sustainabilily 2021, 13, 7. [CrossRef]

22. Pakšiová, R. Reporting of non-financial information on companies in the context of sustainable development in Slovakia. In Proceedings of the 16th International Scientific Conference, Vranov and Dyjí, Czech Republic, 13-15 September 2016.

23. Petera, P.; Wagner, J.; Boučková, M. An Empirical Investigation Into CSR Reporting by the Largest Companies with their Seat in the Czech Republic. In Proceedings of the 22nd Interdisciplinary Information Management Talks, Poděbrady, Czech Republic, 10-12 September 2014; pp. 321-329.

24. Tasáryová, K.; Pakšiová, R. The effects of negative equity on the business performance in Slovakia. In Proceedings of the 28th Interdisciplinary Information Management Talks, Kutná Hora, Czech Republic, 2-4 September 2020; pp. 361-368.

25. Napitupulu, S.; Primiana, I.; Nidar, S.R.; Effendy, N.; Puspitasari, D.M. The effect of Management Capabilities in Implementing Good Corporate Governance: A study from Indonesia Banking Sector. J. Asian Fin. Econ. Bus. 2020, 7, 159-165. [CrossRef]

26. Máziková, K.; Mateášová, M.; Ondrušová, L. Účtovníctvo Podnikatel’ských Subjektov I; Wolters Kluwer: Bratislava, Slovakia, 2016.

27. Šlosárová, A.; Kadlečíková, O.; Kovalčíková, A.; Máziková, K. Účtovníctvo; Wolters Kluwer: Bratislava, Slovakia, 2016.

28. Valaskova, K.; Lazaroiu, G.; Olah, J.; Siekelova, A.; Lancova, B. How capital structure affects business valuation: A case study of Slovakia. Cent. Eur. Bus. Rev. 2019, 8, 1-17. [CrossRef]

29. Srnišová, P. Negative Equity as an Indicator of the Existence of Transactions Between Related Parties. In Proceedings of the 9th International Scientific Conference on MMK 2018, Hradec Králové, Czech Republic, 17-21 December 2018; pp. 381-386.

30. Commercial Code, Act No. 513/1991 Coll., Commercial Code, as Amended. Available online: https://www.slov-lex.sk/pravnepredpisy/SK/ZZ/1991/513/20201001 (accessed on 25 November 2020).

31. Lovciová, $K$. The selected indicators of the state of business property recognized in the financial statements as part of the annual report. In Change Indicators of the Business Property and Their Analysis: Proceedings of Scientific Papers; Bratislava, Slovakia, 2017; pp. 69-82.

32. Košovská, I.; Váryová, I.; Krajčírová, R.; Ferenczi Vaňová, A.; Bojňanský, J. Profit or loss in commercial companies and its allocation in the process of global harmonization. In Proceedings of the International Scientific Conference, Zuberec, Slovakia, 11-13 September 2017; pp. 83-87.

33. Baštincová, A. Objectification of the economic result in relation of the business property. In Proceedings of the International Scientific Conference, Handlová, Ráztočno, Slovakia, 17-18 May 2017; pp. 95-104.

34. Kurnia, P.; Darlis, E.; Putra, A.A. Carbon Emission Disclosure, Good Corporate Governance, Financial Performance and Firm Value. J. Asian Fin. Econ. Bus. 2020, 7, 223-231. [CrossRef]

35. Wardani, R.P. Determinant Factors of Voluntary Disclosure. J. Akunt. Dan Keua. 2011, 14, 1-15. [CrossRef]

36. MacGregor Pelikanová, R. Corporate Social Responsibility Information in Annual Reports in the EU-Czech Case Study. Sustainability 2019, 11, 237. [CrossRef]

37. Pakšiová, R.; Oriskóová, D. Capital Maintenance Evolution using Outputs from Accounting System. Sci. An. Econ. Bus. 2020, 67, 311-331.

38. Jianu, I.; Jianu, I.; Gusatu, I. The physical capital maintenance concept and the new requirements of the economic environment. Afr. J. Bus. Manag. 2011, 5, 13276-13292.

39. Pakšiová, R. The Critical Analysis of Profit for its Allocation Decision-Making. Sci. Ann. Econ. Bus. 2017, 64, 41-56. [CrossRef]

40. Procházka, D.; Pelák, J. Economic Theories of Accounting: The Review of Modern Approaches and their Relevance for StandardSetting. Politická Ekon. 2016, 64, 451-467. [CrossRef]

41. Kubaščíková, Z.; Juhászová, Z. Analysis of financial statements focusing on detection of Ponzi schemes using XBRL. In Proceedings of the 13th International Scientific Conference, Brno, Czech Republic, 27-28 June 2016; pp. 408-412.

42. Cisko, Š.; Klieštik, T. Finančný Manžment Podniku II; EDIS: Žilina, Slovakia, 2013. 
43. Beaver, H.W.; Correia, M.; Mcnichols, F.M. Financial Statement Analysis and the Prediction of Financial Distress. Found. Trends Account. 2010, 5, 99-173. [CrossRef]

44. Šlosárová, A.; Blahušiaková, M. Analýza Účtovnej Závierky, 1st ed.; Wolters Kluwer: Bratislava, Slovakia, 2017.

45. Grünwald, R.; Holečková, J. Finanční Analýza a Plánování Podniku; Ekopress: Praha, Czech Republic, 2004.

46. Bowman, E.H.; Haire, M. A strategic posture toward corporate social responsibility. Calif. Manag. Rev. 1975, 18, 49-58. [CrossRef]

47. Bragdon, J.H.; Marlin, J. Is pollution profitable? Risk Manag. 1972, 19, 9-18.

48. Fogler, H.R.; Nutt, F. A note on social responsibility and stock valuation. Acad. Manag. J. 1975, 18, 155-160.

49. Freedman, M.; Jaggi, B. Pollution disclosures, pollution performance and economic performance. Omega 1982, 10, 167-176. [CrossRef]

50. Simpson, W.G.; Kohers, T. The link between corporate social and financial performance: Evidence from the banking industry. $J$. Bus. Ethics 2002, 35, 97-109. [CrossRef]

51. Spicer, B.H. Investors, corporate social performance and information disclosure: An empirical study. Acc. Rev. 1978, 53, 94-111.

52. Freedman, M.; Jaggi, B. An analysis of the impact of corporate pollution disclosures included in annual financial statements on investors' decisions. Adv. Publ. Int. Acc. 1986, 1, 193-212.

53. Vance, S.C. Are socially responsible corporations good investment risks? Manag. Rev. 1975, 64, 19-24.

54. Register, F.S. Register of Financial Statements 2014-2018. Available online: http:/ / www.registeruz.sk/cruz-public (accessed on 10 February 2020).

55. Finstat. Dataset of Financial Information of Businesses from SR for 2014-2018. Available online: www.finstat.sk (accessed on 25 February 2020).

56. Kubíčková, D.; Jindřichovská, I. Finančná Analýza a Hodnocení Výkonnosti Firem; C.H. Beck: Bratislava, Slovakia, 2015.

57. Szabo, S. Aplikácia Altmanovho Z-skóre ako nástroja predikcie a benchmarkingu. J. Innov. Appl. Stat. 2012,2 , $25-31$.

58. Holečková, J. Finančni Analýza Firmy; ASPI: Praha, Czech Republic, 2008.

59. Růčková, P. Finanční Analýza: Metody, Ukazatele, Využití v Praxis; Grada: Praha, Czech Republic, 2011.

60. Diheneščíková, D.; Hičák, Š. Index IN05 v priemyselných podnikoch na východnom Slovensku. Bus. Türkiye 2011, 2, 39-43.

61. Vochozka, M. Metody Komplexního Hodnocení Podniku; Grada: Praha, Czech Republic, 2011.

62. Hendl, J. Přehled Statistických Metod: Analýza a Metaanalýza Dat; Portál: Praha, Czech Republic, 2015.

63. Hinkle, D.E.; Wiersma, W.; Jurs, S.G. Applied Statistics for the Behavioral Sciences; Houghton Mifflin: Boston, MA, USA, 2003.

64. Svabova, L.; Michalkova, L.; Durica, M.; Nica, E. Business Failure Prediction for Slovak Small and Medium-Sized Companies. Sustainability 2020, 12, 4572. [CrossRef]

65. Gregova, E.; Valaskova, K.; Adamko, P.; Tumpach, M.; Jaros, J. Predicting Financial Distress of Slovak Enterprises: Comparison of Selected Traditional and Learninf Algorithms Methods. Sustainability 2020, 12, 3954. [CrossRef]

66. Shrivastava, S.; Jeyanthi, P.M.; Singh, S. Failure prediction of Indian Banks using SMOTE, Lasso regression, bagging and boosting. Cogent Econ. Financ. 2020, 8, 1729569. [CrossRef]

67. Barbuta-Misu, N.; Madaleno, M. Assessment of bankruptcy risk of large companies: European countries evolution analysis. J. Risk Financ. Manag. 2020, 13, 58. [CrossRef]

68. Zoricak, M.; Gnip, P.; Drotar, P.; Gazda, V. Bankruptcy prediction for small- and medium-sized companies using severely imbalanced datasets. Econ. Model. 2020, 84, 165-176. [CrossRef]

69. Tumpach, M.; Surovicova, A.; Juhaszova, Z.; Marci, A.; Kubickova, V. Prediction of the Bankruptcy of Slovak Companies Using Neural Networks with SMOTE. J. Econ. 2020, 68, 1021-1039.

70. Harumová, A.; Janisová, M. Hodnotenie slovenských podnikov pomocou skóringovej funckie. Ekon. čas. 2014, 62, 522-539.

71. Russ, W.R.; Peffley, W.W.; Greenfield, C.A. The Altman z-score revisited. J. Int. Financ. Econ. 2009, 9, 59-73. [CrossRef]

72. Neumaierová, I.; Neumaier, I. Výkonnost a Tržní Hodnota Firmy; Grada Publishing: Praha, Czech Republic, 2002.

73. Neumaierová, I.; Neumaier, I. Proč se ujal index IN a nikoli pyramidový systém ukazatelů INFA. Ekon. A Manag 2008, 4, 1-10. 